\title{
The EHEA at the Cross-Roads. The Bologna Process and the Future of Higher Education [Overview Paper]
}

\author{
Sjur Bergan
}

\section{Introduction}

The papers in this section address the future orientation of the European Higher Education Area-perhaps by implication also of higher education more broadly. The immediate background is an initiative by several members and consultative members of the BFUG to launch a discussion of the future of the EHEA in preparation of the 2015 Ministerial meeting (Bologna Process 2014a). The debate was launched at the BFUG meeting in Athens in April 2014 (Bologna Process 2014b), was the main issue at the meeting of the BFUG in Roma on September 18-19, 2014 (Bologna Process 2014c) and will also feed into the drafting of the Yerevan Communiqué and the preparation of the Ministerial meeting in May 2015.

The substantial reasons for the debate are more complex. A large majority of EHEA member countries participated in ministerial conferences at political level up to and including 2010, ${ }^{1}$ when the EHEA was formally declared. The Bologna Process helped put higher education reform firmly on the political agenda in Europe as well as in individual countries. Nevertheless, political interest now seems to be waning and at the ministerial conference in București in $2012^{2}$ more countries were represented at senior official than at political level. Is this because there is a feeling that the EHEA has achieved all it was intended to achieve, because the initial goals are now seen as too ambitious and nobody wants to be associated with failure, because the EHEA is seen to lose focus and become everything to all people,

\footnotetext{
${ }^{1}$ An overview of the Ministerial meetings, the Declarations and Communiques adopted and the respective conference web sites will be found at http://www.ehea.info/article-details.aspx? ArticleId=5, accessed January 6, 2015.

${ }^{2}$ http://bologna-bucharest2012.ehea.info/, accessed January 6, 2015.
}

S. Bergan $(\bowtie)$

Council of Europe, Strasbourg, France

e-mail: sjur.bergan@coe.int

(C) The Author(s) 2015

A. Curaj et al. (eds.), The European Higher Education Area,

DOI 10.1007/978-3-319-20877-0_45 
because an increasing focus on implementation implies that the EHEA is now seen as an administrative-some would say bureaucratic-rather than as a political challenge, or simply because as "Bologna" ceases to be new it is also perceived to cease to be innovative and politically interesting?

The perception that the EHEA is seen as being of less political pertinence now that the Area has formally been established is underlined by the relative lack of involvement by a number of countries in the BFUG-by absence or by relatively passive participation where the representatives of several countries only very rarely take the floor in debates - as well as by statements by political decision makers and senior officials and by the education priorities of many participating countries.

The Bologna Process responded to the political agenda of decision makers in the mid- to late 1990s, (see e.g. Attali 1998). In positive terms, it offered a forum for devising common solutions to common challenges, even if these solutions had to be implemented within national frameworks which each had its own traditions and peculiarities. In more negative terms, Ministers may have felt it was easier to undertake difficult reforms challenging set ways and strong interest groups if these could be placed in a European framework, where others had to take similarly strong medicine.

The debate in the EHEA has focused on three questions outlined in the note by the BFUG members and consultative members who launched the debate (Bologna Process 2014a):

1. What are the goals to which Ministers have committed on which work still remains so that commitments will be met?

2. What should be the main goals and issues of the EHEA in the near to medium term?

3. How should the EHEA be organized to achieve these goals?

We might perhaps phrase this in terms of a discussion focusing and what needs to be wrapped up, what needs to be launched, and how the EHEA should be governed and organized.

\section{Unfinished Business}

The first decade of the EHEA - the Bologna Process in the narrow, formal sense of the term-was characterized by strong concentration on structural reforms. Qualifications frameworks, quality assurance, the recognition of qualifications, and transparency instruments remain important elements of both the EHEA and national policy, and were the subject of one of four working groups in the 2012-2015 EHEA work program (Bologna Process 2014d). As Robert Harmsen points out in his contribution (Harmsen 2015), especially in the early years, the goals were clear and the ways in which they would be achieved were considered to be reasonably straightforward. 
However, the formal education structures have largely been reformed, or at least so many public authorities would say. A number of countries have yet to establish and self-certify their national qualifications frameworks or set up quality assurance agencies that comply with the European Standards and Guidelines (Bologna Process 2012). All but Greece have ratified the Lisbon Recognition Convention, but far from all have implemented the provisions of the Convention in their own legislation and practice. The notion that one should look for how a foreign qualification may be recognized rather than how recognition may be denied has still not been universally absorbed. Almost ten years after the deadline by which Ministers pledged to issue the Diploma Supplement automatically, free of charge, and in a widely spoken language, the pledge is still conjugated in the future tense. In its report to the 2015 Ministerial meeting, the Structural Reforms Working Group draws together proposals concerning four policy areas-quality assurance, qualifications frameworks, recognition of qualifications, transparency instruments - to launch the concept of a European infrastructure for transparency and recognition (Bologna Process 2014d).

Nevertheless, the emphasis in structural reforms will shift from developing the structures to implementing them. Learning outcomes need to be put at the center of institutional and individual practice as well as of qualifications frameworks; countries and institutions need to adapt their practice to the requirements of the Lisbon Recognition Convention; and institutions must issue the Diploma Supplements as Ministers promised that institutions would do by 2005. At their 2015 conference, Ministers also seem likely to follow the suggestion by the Structural Reforms Working Group and ask the European Commission, the Council of Europe, and UNESCO to review and revise the Diploma Supplement.

Implementation is a much more challenging task than setting goals. Goals can be set at European level by Ministers. Implementation, on the other hand, relies not only on the public authorities of the 47 member countries of the EHEA, but even more on the adherence and action of higher education institutions, students, and faculty. A shifting emphasis from developing structures to ensuring that they work in practice implies shifting the focus from the European to the national and institutional level, with the attendant risk that uneven national and institutional implementation of what look like compatible structures on paper or, more elegantly, de jure, may mean that these structures will in the end not be compatible de facto.

Focusing on implementation also means that unless something goes drastically wrong, and this is perceived to be either a huge problem or something that can usefully be blamed on political opponents in a national context, a shift from defining policy objectives to implementing them will probably mean reducing the political relevance and - to use one of the catch words of today's new speak-the visibility of the European Higher Education Area.

One important question for the future of the EHEA, then, is how different levels of policy and implementation interact. This has a governance aspect, as Robert Harmsen points out, but governance can best be dealt with as an issue of its own. Armağan Erdoğan (Erdoğan 2015) explores the implementation of Bologna policies in Turkey and demonstrates how the policy goals of the EHEA have guided 
the development of the Turkish higher education system. At the same time, she also shows that the Turkish system responded to many challenges that would have arisen even if the Bologna Process had not been launched. The challenges would perhaps to a large extent have been the same and they arise from demographic as well as societal, international, and technological developments. The solutions devised would, however, not have been flavored à la bolognaise, and developing a higher education system with a considerable degree of compatibility with those of other European countries would possibly not have been an objective. The choice of Turkey for the case study is significant: Turkey is a large European country with an extensive system that has become considerably larger since Turkey joined the Bologna Process in 2001. It is not an EU member but has-or has at least had-EU membership as an important political goal and is, regardless of whether EU membership will materialize, strongly influenced by economic and political developments both within the European Union and in other parts of Europe.

\section{Between Wrapping Up and Launching New Policies: Bologna and the Rest of the World}

Turkey is, as Erdoğan points out in her article, by its geography, its history, and its cultural traditions, an important link between Europe, the Middle East, and Central Asia. Turkey is a country standing on the inside looking out and, perhaps more than most other EHEA countries, in a position to relate to a group of countries standing on the outside looking in.

During its first few years of life, the Bologna Process was essentially inward looking. That was perhaps understandable since the journey toward the European Higher Education Area was an innovative venture into largely unchartered territory, but isolation is rarely a recipe for success. In the classical French tragedy, the ideal is to be loved, but it is better to be hated than to be ignored. At least, as seen by much of the world outside Europe, the Bologna Process was in this enviable ideal situation, even if voices inside Europe were a mix of those ardently in favor and those equally ardently against "Bologna"-but "Bologna" rarely suffered the indignity of being ignored. Avoiding this misfortune in the future is, however, one of the challenges facing the EHEA as it reaches adolescence.

The charge of Eurocentrism may, however, not have been entirely unjustified also beyond the first few years. When the EHEA explicitly opened up to the world with that classical instrument of bureaucracy, a policy strategy (Bologna Process 2007), this was labeled as addressing the global dimension only after a longish and quite ardent discussion on doing away with the term "external dimension". One could perhaps not have blamed those who felt that it connoted too crass a distinction between those on the inside reluctantly looking out, and those on the outside eagerly looking in, possibly with the added message of "stay where you are". 
The interest from other parts of the world was real, and to its credit, the EHEA rose to it, even if it took some time, and the "external" dimension evolved into the global dimension. In my view, the early years of the Bologna Process were more inspired by US higher education than many European policy makers care to admit, and it is significant that the US is also where some of the early interest in "Bologna developments" arose. Attitudes in the US span from Cliff Adelman's enthusiastic assertion that "it is not so much when Bologna will arrive in the US as how" (Adelman 2009), ${ }^{3}$ through Paul Gaston's description of the "Challenge of Bologna" (Gaston 2010), to quite hesitant reactions by several higher education leaders to the Lumina Foundation's attempt at introducing the concept of qualifications frameworks in the US. ${ }^{4}$

Another set of non-EHEA countries interested by the EHEA is discussed by QueAnh Dang (2015). Dang describes how Asia addresses the "challenge of Bologna". Again, the choice of continent is significant. Asia is very likely the continent that European policy makers see as the most significant to their own future, and more often for economic than academic reasons. Europeans, however, often fail to appreciate the diversity of Asia, with countries ranging in population from China and India to the Maldives and Bhutan, and with great diversity of higher education traditions, social inclusion (or the lack thereof), political, social, and religious traditions, and economic performance. Europe is, in my view, a unique balance of what we have in common and what is particular to each country, culture, and tradition. Asia and other continents also blend common and distinct heritages and traditions but, with the possible exception of Latin America and certainly of North America, the balance is more toward diversity.

As Dang clearly describes, to the extent we can refer to a common Asian policy toward the EHEA, it is one of adaptation rather than wholesale importation and copying. This is, in my view, a wise choice. The EHEA may serve as inspiration and can provide a wide array of lessons about measures that have worked and other measures that have worked less well, and EHEA countries can provide important contextual information: what worked and failed in what contexts and circumstances?

QueAnh Dang's article links to the ongoing discussion about how cooperation between the EHEA and the rest of the world should be organized. In 2009, the first Bologna Policy Forum was held end-on with that year's Ministerial conference. The intention was to provide a forum for identifying common issues and possible cooperation between the EHEA and non-EHEA countries. The Bologna Policy Forum was high level, with the participation of most of the ministers who participated in the EHEA Ministerial meeting as well as Ministers and/or high ranking

\footnotetext{
${ }^{3}$ The quote is taken form a presentation Cliff Adelman delivered to the ECTN4 Final Conference "Chemistry and the Bologna Process" on September 9-10, 2009 in Dresden, available at http:// ectn-assoc.cpe.fr/network/ECTN4_FinalConf_Dresden2009/ECTN4FC009_03_Adelman.pdf, accessed January 6, 2015.

${ }^{4}$ At a conference organized by the Lumina Foundation in Washington, DC in July 2009 in which the author participated, attitudes to qualifications frameworks ranged from quite enthusiastic to skeptical.
} 
civil servants from the non-EHEA countries invited. Incidentally, one of theseKazakhstan-joined the European Higher Education Area a year later.

The Bologna Policy Forum was intended as a start, and in 2010 and 2012 similar Fora were held end-on with the Ministerial conferences. However, there is an increasing feeling - in my view justified - that, while the Policy Forum may have made a promising start, this start has not been followed up and that cooperation between the EHEA and other regions has not advanced.

Most likely, there are several reasons for this lack of follow up. One is that many EHEA countries see their cooperation with other countries partly as cooperation and partly as marketing. The two are not always easy to distinguish, and at least for the marketing part, the countries with well-established foreign contacts and that host a large number of students from outside of the EHEA prefer to market their systems as national rather than as part of the EHEA. In the case of EU countries, it matters a great deal whether students come from outside of the EU or not because this will determine the kind of study fees they may be charged. The EHEA has so far not succeeded in developing a common label with which to present itself to the rest of the world and it is unlikely that all members would want it to do so.

Secondly, the politically focused Bologna Policy Fora have not been complemented by more focused cooperation between policy makers and practitioners focused on specific policy areas. This is a statement that immediately needs to be qualified. As Dang points out, the Asia-Europe meeting (ASEM) is a forum for political as well as practical cooperation, and organizations like the European University Association (EUA), EURASHE, the European Students Union (ESU) and ENQA are engaged in cooperation well beyond Europe on topics that are highly relevant to the EHEA. Individual institutions and countries within the EHEA are similarly engaged, and some organizations without formal links to the EHEA have organized EHEA-themed activities. However, while the EHEA is an important reference in many - probably most — of these initiatives, there is no EHEA agenda, coordination, or for that matter financing of such cooperation initiatives.

The relative lack of direction and the tension between cooperation and marketing come to the fore also in the BFUG discussion about how to organize the Bologna Policy Fora. In the view of some members, the format followed so far should be continued, as it allows to gather high ranking representatives of countries from all parts of the world for a policy discussion every two or three years. However, this format has so far not proved a resounding success, and both the level of representation and the participation in the plenary discussions by non-EHEA delegations at the 2012 edition of the Policy Forum indicate that if this is to be the format of future Policy Fora, ways need to be found to make them more attractive and these ways have yet to be identified.

Other BFUG members argue that a new format should be tried, focusing on either a narrow set of policy areas or a narrower set of participating countriespreferably from only one region-or both. In the course of a cycle of Policy Fora, one could potentially cover most regions and a range of policy issues. Neither option is entirely satisfactory and the second is so far untested. In fall 2014, the Bologna Follow Up Group had quite intense discussion on the format of the 2015 
Policy Forum, with members quite divided between those who wanted to keep the current format, and those who considered it necessary to try a new format focusing on a single region at a time and possibly also on a limited number of issues. The compromise solution was a variety of the second, a kind of "single region +" or "single region, but" approach.

\section{Future Priorities}

Even if structural reform have been paramount in the development of the EHEA, other policy areas have also been important. Institutional autonomy, academic freedom, and student participation are underlying values of the EHEA. Even if the degree to which they are present in the debate varies, they were a factor in the negative assessment of Belarus' application to join the EHEA in 2012, as well as in the informal discussions that led to Belarus' refraining from applying for accession in 2005. There are admittedly also concerns about the extent to which these values are reflected in the policies of some current EHEA members. The social dimension has been on the EHEA agenda for at least a decade - it could reasonably be argued that it was introduced at the Praha ministerial meeting in 2001-but there are still somewhat different interpretations of what the social dimension actually comprises and the BFUG has faced problems in defining clear and measurable commitments in this area.

A discussion about future priorities cannot, therefore, be entirely divorced from a consideration of what has been achieved so far and what issues need to be wrapped up. The discussion about the future orientation of the EHEA at and leading up to the 2015 Ministerial conference will be an important milestone, but it will not be a complete hiatus. It will be a reorientation, but not a turnaround.

Structural reforms have been discussed in some detail above. It seems very likely that whatever else will be on the "Bologna agenda", structural reforms will be in a prominent position. How can the EHEA prevent uneven implementation of EHEA policies from undermining the idea of a European Higher Education Area with coherent structures? Broad coordination of both national policies, including legislation, and the practice of higher education institutions will be needed, but it is unclear how this could be achieved and financed, all the more so as countries that are less advanced in their development of national qualifications frameworks and quality assurance provision will not all be able or willing to finance broad participation in activities like policy seminars and peer learning projects.

It is also unclear whether countries are willing to undertake extensive new obligations in this area. For example, the Structural Reforms Working Group (SRWG) proposes that countries review their legislation to ensure that it be compatible with the Lisbon Recognition Convention (Bologna Process 2014d, pp. 70-71). This is an important proposal and it should be straightforward since one can reasonably assume that when countries ratify an international treaty they intend to adjust their national legislation within reasonable time. Nevertheless, experience suggests that his may be 
too rosy a view of reality, as borne out by the analysis of the national action plans submitted by Ministers prior to the 2007 Ministerial conference (Rauhvargers and Rusakova 2010). The SRWG also proposes that the Diploma Supplement be reviewed (Bologna Process 2014d, p. 74). This makes sense because the current Supplement antedates the EHEA and was developed by the Council of Europe, the European Commission, and UNESCO in the mid- to late 1990s. Since the Diploma Supplement belongs to three international institutions and two different frameworks - the Lisbon Recognition Convention and Europass - reviewing it will be a complex undertaking, and this is further underlined by the fact that it has acquired legal status in some countries. That the process will be complex is, however, not a reason not to launch it.

On the other hand, positions do evolve. In 2005 Ministers rejected a proposal that short cycle qualifications be included in the overarching framework of qualifications of the EHEA (QF-EHEA), and watered the text of the Bergen Communiqué (Bologna Process 2005) down to say these qualifications could be included within the first cycle in national frameworks. Ten years later, the Structural Reforms Working Group proposes that short cycle qualification at long last be recognized explicitly in the QF-EHEA (Bologna Process 2014d, p. 63) and this proposal was accepted by the BFUG without objections.

Structural reforms have been prominent in the "Bologna agenda" because they were high on the agenda of many Ministers in the late 1990s, when the Bologna Process was launched. This alone was insufficient: structural reforms fulfilled two additional criteria: it was possible to define relatively clear objectives (a point also made by Harmsen 2015), and they lent themselves to the relatively loose kind of international cooperation that has been a hallmark of the EHEA, more about which when we turn to governance. The challenge will be to find policy areas that fulfill all three criteria. The financing of higher education is high on the agenda of all ministers but it is unclear to what extent clear goals can be defined that are seen as relevant by all — or at least the great majority of - the 47 EHEA countries, which have vastly different financial capacities, very different views on the proper balance between public and private funding, and a very broad range of financial support systems for students, ranging from reasonably generous to almost absent. In Leuven/Louvain-la-Neuve (Bologna Process 2009) the Ministers agreed to aim for $20 \%$ mobility by 2020 . That this goal is among the pending issues of the EHEA is mainly due to the fact that mobility has increased far less than had been expected when the Bologna Process was launched, but it may also become an issue of defining what the seemingly straightforward "20\%" actually means when the time comes to assess whether the goal has been reached.

\section{Governance}

It would be difficult to imagine an international cooperation arrangement that is much more loosely organized than the EHEA. In the early years, what is now the Bologna Follow Up Group was chaired by the country holding the EU presidency, 
and this country also provided the secretariat. At the Praha Ministerial meeting, Ministers established what is now the Bologna Board (then called a preparatory group) and also established a group of consultative members - at least that is how the text ${ }^{5}$ was interpreted (Bologna Process 2001). At the Berlin meeting, Ministers decided that the Bologna Secretariat should be provided by the country hosting the following ministerial conference for the entire period between the two conferences (Bologna Process 2003) and in Leuven/Louvain-la-Neuve they decided that the BFUG should be co-chaired by the country holding the EU Presidency as well as by a non-EU country (Bologna Process 2009).

That is, in a nutshell, the formal organization of the EHEA. The organization has been so informal that the BFUG has at times managed to adopt different voting rules for different issues. At one point, the rules said that countries offering to host a ministerial conference were not allowed to vote on the proposal, whereas countries running for the Bologna Board at the time when a part of the membership was elected were allowed to vote, albeit with the provision that they not vote for themselves. The rules did, however, not specify how this particular provision was to be enforced in a vote by secret ballot.

There is strong attachment within the BFUG to this loose organizational structure and any suggestion that a stronger structure might be needed has been met with resistance. This applies to the possibility of establishing the European Higher Education Area through an international convention, discussed in the run-up to the Bergen Ministerial conference in 2005, as well as an initiative by the Council of Europe's Parliamentary Assembly to have the Bologna Secretariat established in the Council of Europe (Council of Europe 2009). This initiative did not have the support of the Council of Europe's Steering Committee for Higher Education and Research or of the Secretariat, since we were convinced the Council of Europe would serve the EHEA better as a consultative member, and also because we were well aware that the proposal did not have support among EHEA members.

The European Higher Education Area has two important functions: it is a formal framework within which members establish coherent and compatible higher education policies and it is a set of good practices. In the former sense, the EHEA is a framework of which a country is a member or it is not, and it is a framework relying on certain structures. These include the Bologna Follow Up Group and Board, working groups and the Bologna Secretariat. Individual higher education institutions are not members of the EHEA, whose members are governments. Higher education institutions belong to the higher education system of a country that is a member of the EHEA or they do not. These are fairly loose and informal structures but they are clearly established and the membership is clear.

In the second sense, the EHEA is a community of practice and the examples of good practice are available to everyone. Public authorities, higher education

\footnotetext{
5"The European University Association, the European Association of Institutions in Higher Education (EURASHE), the National Unions of Students in Europe and the Council of Europe should be consulted in the follow-up work."
} 
institutions, and individual faculty and students may be inspired by good examples developed within the EHEA regardless of whether they work in an EHEA country or not - that is an important point raised in QueAnh Dang's article. As Robert Harmsen points out, policy learning is an important aspect of the EHEA also for EHEA members.

What kind of governance arrangements the EHEA will need in the future depends to a large extent on what vision members have for its future. The more that vision tilts toward mutual learning and exchange of good practice, the less formal the governance model needs to be. The more the EHEA is seen as a framework within which students and faculty can move as freely as possible thanks to common or at least compatible structures, such as qualifications frameworks and standards for quality assurance, and the more EHEA members are seen as undertaking obligations toward each other, the stronger will be the need for a governance model that can ensure that structures remain compatible and that mutual obligations be honored.

So far there is a sense that the governance structures should be as informal as possible, but there is no discernible consensus on exactly what this means. The stock taking exercises that were launched in 2003, with the first stock taking report presented to the Bergen meeting in 2005, originally relied on self-reporting by members. Since then, the reporting has been strengthened by the important contribution of Eurydice and others so that the current Implementation reports are seen as considerably more objective and reliable than the first reports. There is, however, no consensus on what consequences, if any, the Implementation Reports should have in relation to countries that are far from implementing specific policy goals. This is illustrated by the fact that the only issue on which the SRWG delivered a split recommendation to the BFUG meeting of November 27-28, 2014 was a recommendation to the effect that the BFUG co-chairs and the Bologna Secretariat be mandated to contact the competent authorities of EHEA members with an unsatisfactory implementation of structural reforms in the 2015 EHEA Implementation Report with offers of assistance. After some debate, the BFUG accepted the thrust of this recommendation but softened the wording to emphasize offers of policy dialogue (Bologna Process 2014d, p. 24).

One issue, then, is the degree to which the EHEA may or may not need a BFUG with a stronger mandate than it currently has. Another is the relationship between BFUG members and the political leadership of their Ministries. Today, this varies considerably. In some cases, the BFUG members have close contacts with their political leadership and are known - or at least widely assumed - to speak with authority on behalf of their countries. In other cases, it is much less clear whether BFUG members effectively speak on behalf of the political leadership or merely on their own behalf. BFUG members are of course unlikely to announce that they do not consult with or do not have the ear of their political decision makers, but a formal announcement is not always needed for the impression to develop. A stronger governance of the EHEA would therefore also require that BFUG members have stronger and more explicit mandates from their own political decision makers. 
The third element of the governance model is the Bologna Secretariat. As we have seen, the Secretariat structure has already evolved from one provided by the Chairmanship country of the BFUG, and therefore changing every six months, to one based in and provided by the host country of the following ministerial conference. The Secretariat therefore serves for two or three years, depending on the timing of the Ministerial conferences, and this has meant a better back up for the BFUG than what was provided in the early years, even though several of the rotating secretariats linked to the BFUG Chairmanships did a very good job under the circumstances, possibly with the Greek chairmanship and secretariat in spring 2003 as the outstanding example.

When the current Secretariat arrangements were launched in fall 2003, there was a discussion of whether countries could be invited to second officials to the Secretariat and Norway, which hosted the first Secretariat of this kind, stated that it would have welcomed secondments. However, none materialized and possible practical arrangements, e.g. with a view to offsetting the high cost of living in Norway for officials seconded from countries with lower salaries, were never explored. The discussion of whether to divorce the Secretariat from the hosting of the next Ministerial conference has now been relaunched but the consequences have so far not been spelled out in any great detail. With the exception of the Secretariat serving between 2007 and 2010, which was provided jointly by Belgium (both communities), Luxembourg, and the Netherlands and based in Bruxelles/Brussel under Belgian legislation, all Secretariats since 2003 have been made up of residents of the host country of the Secretariat and hired under the labor legislation of that country.

If this model were to be changed, there seem to be three broad options. In the first option, the Secretariat could be attached to or become a part of an existing international organization, in which case the framework of operation would be clear, but as we have seen, any suggestions in this sense have met with considerable resistance, and no organization has actually offered to provide or host the Bologna Secretariat. The second option would be to establish the Secretariat as an independent entity, but this would require that many complex legal issues be clarified, including the legislation under which the Secretariat would operate and its staff be hired and - in the worst of cases - fired, what the social security arrangements for staff members would be, and who would bear ultimate financial and legal responsibility for the Secretariat and its staff. The third option would be to establish the Secretariat as part of an existing national structure and encourage and make arrangements for secondments from other EHEA members, as France has now done in its invitation to host the Secretariat in 2015-18 and the ministerial conference in 2018. This would be legally less complex, but arrangements for secondments would need to be established, possible top up salaries secured, and there would need to be agreement on, as well as acceptance by the host country of, the period for which the Secretariat would be established. Since the purpose of divorcing the Secretariat from the hosting of the following Ministerial conference would be to provide greater continuity, it would presumably need to be established for a period that would span at least two Ministerial conferences, preferably longer. 
The fourth element of governance is financing. Rather, it is listed here as the fourth element because it has not been very prominent in the BFUG discussion of the "future of Bologna", but it may well be argued that financing is the first element in order of importance. The fact that the EHEA has no independent budget might be seen as both a reason for and consequence of its loosely organized governance. For a process in which policy goals are agreed at European level but implemented nationally and within higher education institutions, not having an "EHEA budget" may not seem an unnatural option. It does, however, mean that no EHEA body can decide to allocate resources to assist countries or institutions with implementing policies or develop projects that could have particular relevance to the future development of the EHEA or to launch research on a particular issue of policy or implementation, nor does the EHEA have the resources to bring together practitioners for peer learning activities or promote and develop the global dimension of the EHEA.

Individual countries, of course, do have resources and so does the European Commission. To put it bluntly, the EHEA would not have been possible had the Commission not provided massive financial support for various initiatives and also had the Commission not extended such support to almost all EHEA countries, rather than just those that are either EU members or participating in given EU programs. ${ }^{6}$ However welcome financial support by the European Commission and individual countries is, these are for obvious reasons hesitant to delegate authority over their own budgets to the BFUG and there is therefore no EHEA budget in the real sense of the term. It is difficult to see how the governance of the EHEA could be significantly strengthened without some kind of EHEA budget over which the BFUG would have decision making authority. At the same time, it is difficult to see how an EHEA budget in this sense could be established today, when most EHEA members suffer cuts in public budgets coupled with increasing demands for accountability.

\section{Toward a Conclusion}

Drawing a conclusion concerning the future is by definition a Sisyphean task. At the time of writing, the BFUG has not made final recommendation to ministers and ministers have not adopted their Yerevan Communiqué, which will be the policy

\footnotetext{
${ }^{6}$ This was, incidentally, the framework for membership of the Bologna Process until 2003, when it was decided that "Countries party to the European Cultural Convention shall be eligible for membership of the European Higher Education Area provided that they at the same time declare their willingness to pursue and implement the objectives of the Bologna Process in their own systems of higher education." (Bologna Process 2003). By way of contrast, the Prague Communiqué noted that "Ministers welcomed new members to join the Bologna process after applications from Ministers representing countries for which the European Community programmes Socrates and Leonardo da Vinci or Tempus-Cards are open.” (Bologna Process 2001).
} 
instruments through which they may reorient the EHEA. There are therefore still opportunities for higher education practitioners and policy makers at different levels to make their voices heard. This section of the books arising from the Bologna Researchers Conference provides a valuable contribution to this debate through three reasoned and well-researched contributions as well as, it is hoped, through this essay brining the section together. Rather than seeking to draw an overriding conclusion from three contributions that all stand on their own and that approach the "future of Bologna" from different angles, I would like to offer a final thought from yet another angle.

With the possible exception of "employability", there is hardly a word that occurs as frequently in current education debate as "quality". However, quality is more often than not presented as an established entity, something that is "out there" and all we have to do is strive for it and preferably achieve it. However, it makes little sense to assess whether we do something well unless we know what we are trying to do in the first place. The quality debate may be rich in describing ways of reaching and not least measuring quality, but it is surprisingly divorced from considerations of what purposes education should serve (Bergan 2005; Council of Europe 2007, 2012).

Consideration of the link between higher education reform and the broader purposes of higher education has also been subdued in the development of the EHEA. This is not to say it has been absent. The EHEA builds on a set of values that comprise academic freedom, institutional autonomy, and student participation, and several communiqués refer to the multiple purpose of higher education.

Nevertheless, a relaunch of the European Higher Education Area, intended to give higher education policy the place it deserves in European debate, but equally to give European societies the kind of higher education they deserve and that they need for their future developments, will require a much more sustained debate on the kind of Europe we would like to have and the kind of education we will need to achieve our goal. This debate will need to be philosophical and practical at the same time, since it will need to establish a clear connection between principles, policy, and practice. That will hopefully (re)motivate the higher education community, the policy making community, and our community tout court. It is the kind of debate to which the present author has sought to contribute (Bergan 2011) and to which the following quote from the Canadian philosopher John Ralston Saul is highly relevant:

And so I find our education is increasingly one aimed at training loyal employees, even though the state and the corporations are increasingly disloyal. What we should be doing is quite different. It turns on our ability to rethink our education and our public expectations so that we create a non-employee, non-loyal space for citizenship. After all, a citizen is by definition loyal to the state because the state belongs to her or him. That is what frees the citizen to be boisterous, outspoken, cantankerous and, all in all, by corporatist standards, disloyal. This is the key to the success of our democracy (Saul 2009).

I would argue that the development of the European Higher Education Area has so far seen four distinct phases. The first phase, encompassing the ministerial conferences at Sorbonne in 1998, in Bologna in 1999, and Praha in 2001, was one 
of launching the march toward the EHEA. It was an exciting phase but also a relatively easy one, since ministers could focus their attention on setting goals that would be achieved a decade hence.

The second phase, marked by the ministerial conferences in Berlin in 2003 and Bergan in 2005, was one of development, and it was in this phase that two key EHEA instruments - the ESG and the QF-EHEA were first launched (Berlin) and then adopted (Bergen). At the same time, this phase was also marked by the sobering realization that, if the EHEA was to be based on its members achieving their stated goals by 2010, one also had to assess the progress members made toward those goals. This was the origin of the stocktaking reports, launched in 2003 and submitted for the first time in 2005. This was also the phase in which the EHEA became truly European with the broadening of the access criteria and an increase of the number of member states from 33 in 2001 through 40 in 2003 to 45 in 2005.

The third phase, from London in 2007 through Leuven/Louvain-la-Neuve in 2009 to Budapest and Wien in 2001-was one of consolidation. Some new initiatives were launched, including the Global Dimension Strategy (Bologna Process 2007), the Bologna Policy Forum and the " $20 \%$ by 2020 " mobility goal, but as 2010 drew nearer, attention focused on fulfilling commitments already undertaken rather than defining new objectives.

The fourth phase comes with the establishment of the EHEA in 2010 and is marked by the București conference in 2012. In this phase, the EHEA continues to develop, but at the same time there is diminishing political interest in the EHEA, higher education is affected by the financial crises - which admittedly began already in 2008 - and there is considerable uncertainty as to how the EHEA should develop further.

Whether the discussions that these uncertainties have given rise to and that form the backdrop of this section of the books will lead to the Yerevan conference in May 2015 being considered as a fifth phase of the EHEA and a new start is one of the great challenges of the EHEA as it will hopefully develop from adolescence to full maturity.

Open Access This chapter is distributed under the terms of the Creative Commons Attribution Noncommercial License, which permits any noncommercial use, distribution, and reproduction in any medium, provided the original author(s) and source are credited.

\section{References}

Adelman, C. (2009). The Bologna Process for U.S. eyes: Re-learning higher education in the age of convergence. Washington, DC: Institute for Higher Education Policy, Retrieved from http:// files.eric.ed.gov/fulltext/ED504904.pdf. Accessed January 6, 2015.

Attali, J. (1998). Pour un modèle européen d'enseignement supérieur: rapport à M. le ministre de l'éducation nationale, de la recherche et de la technologie. Retrieved from http://www. ladocumentationfrancaise.fr/var/storage/rapports-publics/984000840/0000.pdf. Accessed January $6,2015$. 
Bergan, S. (2005). Higher education as a 'public good and a public responsibility': what does it mean? In L. Weber \& S. Bergan (Eds.), The public responsibility for higher education and research. Council of Europe Higher Education Series No. 2. Strasbourg: Council of Europe Publishing.

Bergan, S. (2011). Not by bread alone. Council of Europe Higher Education Series No. 17. Strasbourg: Council of Europe Publishing.

Bologna Process. (2001). Towards the European higher education area Communiqué of the meeting of European Ministers in charge of Higher Education in Prague on May 19th 2001. Retrieved from http://www.ehea.info/Uploads/about/PRAGUE_COMMUNIQUE.pdf. Accessed January 6, 2015.

Bologna Process. (2003). Realising the European higher education area. Communiqué of the Conference of Ministers responsible for Higher Education in Berlin on September, 192003. Retrieved from http://wwwehea.info/Uploads/about/Berlin_Communique1.pdf. Accessed January 6, 2015.

Bologna Process. (2005). The European higher education area-achieving the goals. Communiqué of the Conference of European Ministers Responsible for Higher Education, Bergen, May 19-20, 2005. Retrieved from http://www.ehea.info/Uploads/about/050520_ Bergen_Communique1.pdf. Accessed January 6, 2015.

Bologna Process. (2007). European higher education in a global setting. A Strategy for the external dimension of the Bologna Process. Retrieved from http://www.ehea.info/Uploads/ Global\%20context/Strategy-for-EHEA-in-global-setting.pdf. Accessed January 6, 2015.

Bologna Process. (2009). The Bologna process 2020: The European higher education area in the new decade. Communique of the Conference of European Ministers Responsible for Higher Education, Leuven and Louvain-la-Neuve, April, 28-29, 2009. Retrieved from http://www. ehea.info/Uploads/about/Leuven_Louvain-la-Neuve_Communiqu\%C3\%A9_April_2009.pdf. Accessed January 6, 2015.

Bologna Process. (2012). The European higher education area in 2012: Bologna process implementation report. Retrieved from http://www.ehea.info/Uploads/\%281\%29/Bologna\% 20Process\%20Implementation\%20Report.pdf. Accessed January 6, 2015.

Bologna Process. (2014a). Bologna Process revisited. Document BFUG_GR_KZ_39_5a.

Bologna Process. (2014b). Minutes of the meeting of the BFUG Athens April 9-10, 2014. Document BFUG_IT_VA_41_5b. Retrieved from http://archiveehea.info/folder?year_ selected=347\&issued_by $=374$. Accessed January 6, 2015.

Bologna Process. (2014c). Minutes of the meeting of the BFUG Roma September 18-19, 2014.

Bologna Process. (2014d). Report by the EHEA working group on structural reforms. Final version of December 8, 2014. Retrieved from http://wwwehea.info/Uploads/SubmitedFiles/12 2014/154923.pdf. Accessed January 6, 2015.

Council of Europe. (2007). Recommendation Rec/CM(2007)6 of the Committee of Ministers to member states on the public responsibility for higher education and research. Retrieved from https://wcd.coe.int/ViewDoc.jsp?id=1135191\&Site=CM\&BackColorInternet=C3C3C3\&Back ColorIntranet=EDB021\&BackColorLogged=F5D383. Accessed January 6, 2015.

Council of Europe. (2009). Recommendation 1892 (2009) by the Parliamentary Assembly on the contribution of the Council of Europe to the development of the European Higher Education Area. Retrieved from http://assembly.coe.int/nw/xml/XRef/Xref-XML2HTML-en.asp?fileid= 17791\&lang=en. Accessed January 6, 2015.

Council of Europe. (2012). Recommendation Rec/CM(2012)13 of the Committee of Ministers to member States on ensuring quality education. Retrieved from https://wcd.coe.int/ViewDoc. jsp?id=2014671\&Site=CM\&BackColorInternet=C3C3C3\&BackColorIntranet=EDB021\& BackColorLogged=F5D383. Accessed January 6, 2015.

Dang, Q. A. (2015). The Bologna Process Goes East? From 'Third Countries' to Prioritizing Inter-regional Cooperation between the ASEAN and EU.

Erdoğan, A. (2015). Current and future prospects for the Bologna Process in the Turkish higher education system. 
Gaston, P. L. (2010). The challenge of Bologna. What United States higher education has to learn from Europe, and why it matters that we learn it. Sterling, VA: Stylus Publishing.

Harmsen, R. (2015). Future scenarios for the European higher education area: Exploring the possibilities of 'experimentalist governance'.

Rauhvargers, A., \& Rusakova, A. (2010). Improving recognition in the European higher education area: An analysis of national action plans. Strasbourg: Council of Europe Publishing Council of Europe Higher Education Series No. 12.

Saul, J. R. (2009). A fair country. Telling truths about Canada. Toronto, Ontario: Penguin Canada. 